\title{
СПОСОБИ ПЕРЕКЛАДУ ТЕРМІНІВ УКРАЇНСЬКОЮ МОВОЮ 3 АНГЛІЙСЬКОЇ
}

Фурт Д. В. Способи перекладу термінів українською мовою з англійської. У статті з'ясовано особливості перекладу безеквівалентних термінів українською мовою. Узагальнено визначення поняття «термін» у лінгвістиці, виокремлено спільні риси у визначеннях поняття різними науковцями, окреслено (ㄱ Д. В. Фурт, 2018. 
основні характеристики терміна. Розглянуто способи перекладу англійських термінів українською мовою та визначено особливості кожного. Особливу увагу приділено перекладу багатокомпонентних термінів та визначено основні етапи їх перекладу (аналітичний та синтетичний); розглянуто основні причини неправильного перекладу, надано поради щодо їх усунення.

Ключові слова: безеквівалентні терміни, абсолютний та відносний еквівалент, запозичення, транскодування, калькування, описовий переклад, інверсія.

Фурт Д. В. Способы перевода терминов из украинского языка на английский.

В статье выяснены особенности перевода безэквивалентных терминов на украинский язык; обобщенно определение понятия «термин» в лингвистике, выделены общие черты в определениях понятия разными учеными и обозначены основные характеристики термина. Рассмотрены способы перевода английских терминов на украинский язык и обозначены особенности каждого. Особое внимание уделено переводу многокомпонентных терминов и определены два основных этапа их перевода; рассмотрены основные причины неправильного перевода и даны советы по их устранению.

Ключевые слова: безэквивалентные термины, абсолютный и относительный эквивалент, заимствование, транскодирование, калькирование, описательный перевод, инверсия.

Furt D. V. Ways of translating terms from English into Ukrainian.

This article develops the basics of the theory of English terms into Ukrainian. The peculiarities of non-equivalents terms translation into Ukrainian are determined; general definition of the notion «term» in linguistics is generalized, common features in notion definitions by different scientists are outlined and term main characteristics are indicated. The ways of translating English terms into Ukrainian are considered and the features of each method are outlined. Particular attention is paid to the translation of multicomponent terms and defined two main stages of their translation; the main incorrect translation causes are considered. Translating terms from English into Ukrainian, linguists are primarily trying to find a lexical equivalent - a constant lexical correspondence that exactly coincides with the meaning of the word. This task is rather complicated, since many terms have appeared relatively recently, therefore it is not always possible to impose them on the realities of our country. If it is impossible to find absolute equivalents then the absolute equivalent of the relative is allowed. Among the ways of translating terms the next ones are considered: the untranslatable adoption of terms method (it is not recommended for widespread use, since «excessive adoption» is often carried out, while in the language the equivalent of the term already exists), adaptive transcoding (it is recommended to use if it is necessary to create a clearly
(С Д. В. Фурт, 2018. 
defined term), linguistic calque (in some cases this method is integral for translating specialized terms), explication or descriptive translation (when a simple term is replaced by a phrase that absolutely conveys its meaning), inversion (change the phrase components order) and substantiation (using Ukrainian word with a narrower subjectlogical meaning than the English one has). While translating non-equivalents terms, a combination of several translation techniques can be combined simultaneously. Complex terms translation involves two stages: analytical and synthetic. When translating the terms, it is necessary to take into consideration the context of the whole text. The translation of terms is the core of scientific and technical translation, so it is important to know the features of the translation of this vocabulary layer to achieve maximum equivalence.

Key words: non-equivalent terms, absolute and relative equivalents, untranslatable adoption, transcoding, linguistic calque, descriptive translation, inversion.

Опис та аналіз науково-технічних терміносистем є одним із провідних напрямів лінгвістичних досліджень останніх десятиліть. Підвищений інтерес до питань спеціальної номінації пояснюється роллю термінології та іiі стандартизацією в різних галузях знання. Задля досягнення єдиного позначення та розуміння сутності й процесів навколишнього світу, а також задля отримання максимальної ефективності від діяльності фахівців у сферах науки i виробництва сьогодні розв'язуються проблеми уніфікації та гармонізації термінології. Процес упорядкування науковотехнічного простору багато в чому залежить від подолання мовної розосередженості в професійних сферах знання, тому в лінгвістиці першочергове значення мають дослідження, спрямовані на подолання мовних бар'єрів у професійних сферах діяльності. Термінологи (В. Виноградов, Г. Винокур, О. Смірницький) вивчають процес термінотворення, закріплення терміна в терміносистемі, виявляють основні механізми номінації, здійснюють цілеспрямовану діяльність для досягнення еквівалентності перекладу термінологічної лексики, для встановлення коректних міжмовних відповідностей термінологічних понять на національному та міжнародному рівнях. Термінологічна система - складний лексичний пласт. ๑ Д. В. Фурт, 2018. 
На думку Л. Дінес, термінологія будь-якої галузі знання знаходиться в стані постійної кількісної та якісної зміни. Одні терміни виходять 3 ужитку, створюються інші, що позначають нові поняття або більш точно передають зміст старих [5].

Незважаючи на різні підходи до визначення поняття «термін» (функціональний, комунікативний, когнітивний тощо), більшість дослідників дотримуються позиції, що «термін» - це слово або словосполучення, яке означає спеціальне поняття i містить наукову інформацію. Нам імпонує визначення поняття «термін», запропоноване В. Лейчиком. Науковець наголошує, що термін - це лексична одиниця певної мови для спеціальних цілей, що позначає загальне, конкретне або абстрактне поняття спеціальної сфери знань або діяльності [9, с. 31-32].

Питання специфіки термінів та способів їх перекладу розглядали у своїх працях багато мовознавців: Г. Агапова, Л. Алєксєєва, Н. Александрова, І. Арнольд, О. Ахманова, І. Багмут, В. Виноградов, Г. Винокур, В. Даниленко, Т. Кияк, В. Комісаров, В. Лейчик, М. Мартем'янова, С. Радецька, О. Реформатський, Я. Рецкер, О. Смірницький, С. Хоменко та інші. Проблеми перекладу іншомовних слів розглядаються в публікаціях І. Кікець та Н. Кікець «До питання про деякі труднощі при перекладі термінів та шляхи їх подолання» [7], Н. Сапальової «Використання в українському перекладі науково-технічних термінів іншомовного походження» [12].

3 погляду А. Суперанської та Н. Подольскої, термін однозначний, не має конотативних значень, позбавлений синонімів, незалежно від тексту термін перекладається терміном повним або абсолютним еквівалентом, і тому відповідно до думки багатьох спеціалістів, належить до одиниць, які не ускладнюють роботу перекладача [6]. Однак Л. Борисова акцентує увагу, що не в усіх ситуаціях переклад терміна $\epsilon$ безпроблемним процесом через те, що різні галузі знань уміщують у собі одну й ту ж одиницю, яка має різне значення залежно від контексту [3]. 
Тож мета статті полягає в розгляді особливостей перекладу безеквівалентних термінів українською мовою.

Під час перекладу термінів 3 англійської мови українською лінгвісти передусім намагаються знайти лексичний еквівалент постійна лексична відповідність, яка точно збігає зі значенням слова. Це завдання $є$ складним, оскільки багато термінів з'явилися відносно нещодавно, тому не завжди можливо їх накласти на реалії в нашій країні. В. Карабан наголошує на необхідності вміти находити відповідний еквівалент у рідній мові та розширювати знання термінів-еквівалентів [6]. Прикладом пошуку еквівалента $є$ : еquipment - техніка, оснащення.

Як зазначає Е. Скороходько, подекуди неможливо віднайти абсолютні еквіваленти. Якщо зміст поняття частково відображений у тексті, то допускається заміна абсолютного еквівалента відносним. Під відносним еквівалентом розуміють термін, який виражає поняття, родове щодо поняття, яке виражене терміном. Відносний еквівалент може використовуватися лише в такому контексті, який дає змогу відновити видові ознаки об'єкта. Відносні еквіваленти застосовують у тому разі, якщо абсолютний еквівалент виявляється занадто громіздким. Наприклад, абсолютним еквівалентом англійського терміна share without par value є акція без номінальної вартості, а відносним може бути просто акиія (якщо контекст дозволяє) [13].

$\mathrm{У}$ наш час активно розвиваються міжкультурні й міжмовні контакти в різних сферах діяльності, що спричиняе інтенсивну появу мовного запозичення. Спосіб безперекладного запозичення термінів реалізується через транскрипцію або транслітерацію: бьорглері (burglary), фелонія (felony), гендер (gender), девиантность (deviance), стратифікація (stratification), а також численні латинські вираження: ад хок (ad hoc), де факто (de facto), де юре (de jure).

Хоч в українській мові $є$ еквіваленти означених англійських слів, вони не будуть повною мірою мати той сенс, який криється ๑) Д. В. Фурт, 2018. 
в англійських поняттях. Наприклад, для українського слова стать в англійській мові є два еквіваленти - це і sex i gender, однак ці слова не є синонімами. I для розмежування значення залучення до лексичного складу української мови терміна гендер обгрунтовано.

Такий метод $\epsilon$ необхідним в окремих ситуаціях та не рекомендується для широкого застосування, оскільки часто відбувається «надмірне запозичення», тоді як у мові вже функціонує еквівалент терміна.

Під час транскодування літерами може передаватися вся форма або більша іiі частина. Іноді застосовується змішане транскодування, коли більша частина транскодованого слова відбиває його звучання, проте водночас передаються й деякі елементи його графічної форми [4]. Як зазначає Л. Білозерська, транскодування термінів відбувається в тих випадках, коли в мові відсутнє відповідне поняття та відповідний перекладний еквівалент, а перекладач не може дібрати слово або слова в мові перекладу, які б адекватно передавали зміст поняття та задовольняли вимоги термінотворення. Оскільки у процесі транскодування слово має одне значення, то такий спосіб перекладу доцільно застосовувати, коли в мові перекладу необхідно створити чітко однозначний термін [2].

Останнім часом почастішали випадки, коли такі способи перекладу термінів не мають логічних підстав. Так, наприклад, нещодавно з'явилися такі псевдо-терміни, як атітьюди (attitudes), структураиії (structuration), егалітарний (Egalitarian), детермінація (determination). Використання таких термінів не $\epsilon$ обгрунтованим, адже в українській мові є точні еквіваленти, які чітко відображають сутність англійських концептів (агенти / суб'єкти, установки, структурування, рівний / рівноправний, визначення).

Запозичення пояснюються «мовною модою» $\mathrm{i} \epsilon$ «порожніми» концептами (англомовними варваризмами).

Наступним методом перекладу термів є калькування, що 
передбачає наявність двосторонніх міжмовних відповідностей між лексичними одиницями. Подекуди калькування $є$ невід'ємним способом перекладу спеціалізованої лексики. Наприклад, термін Benchmark означає вихідні дані, на які керівництво компанії звертає пильну увагу, коли формує будь-які стратегї. Терміном benchmarking зазвичай виражається процес виявлення головних стратегічних показників i визначення цільових значень цих показників на основі стратегічних завдань. Означене поняття вже закріпилося в економічній терміносистемі української мови. За допомогою калькування можна перекласти такі терміни: discontinuity - припинення діяльності, provision - постачання, temporary difference - тимчасові різниці, тощо.

Для перекладу термінів використовується також прийом описового перекладу (експлікація). Описовий переклад - це такий прийом перекладу нових лексичних елементів вихідної мови, коли простий термін замінюється в мові перекладу словосполученням, яке адекватно передає зміст цього простого терміна [6, с. 36]. На такий переклад ми можемо натрапити в тлумачних словниках. Прикладами описового методу можуть бути: diluted earnings per share - розбавлений прибуток на звичайну акцію; basic earnings per share - чистий прибуток у розрахунку на акиію, market auction торгівля цінними паперами тощо.

На думку Е. Акопової, недоліком прийому $\epsilon$ його громіздкість, яка значно ускладнює текст [1]. В. Борщовецька наголошує, що описове словосполучення порушує таку вимогу до термінів, як стислість (а тому такі багатослівні терміни не мають дериваційного потенціалу, тобто, від них важко, якщо загалом можливо, утворювати похідні терміни [4].

Наступним способом перекладу термінів вважають «інверсію»- переклад зі зміною порядку компонентів словосполучення [11, с. 20-21], як-от: cartographical production's publication - видання картографічної продукиії, spatial data's updating - оновлення просторових даних.

(ㄱ Д. В. Фурт, 2018. 
Серед способів перекладу безеквівалентних термінів виокремлюють також метод конкретизації. Методом конкретизації вважається використання під час перекладу слова 3 вужчим предметно-логічним значенням ніж в англійській мові. Наприклад, quadrangle name - номенклатура, state plane coordinates державна система координат. Цей спосіб перекладу зумовлений відсутністю повної відповідності між словами 3 широкою семантикою англійської мови в українській мові. Зазвичай у словниках подано кілька варіантних відповідностей, кожне 3 яких передає лише одне з приватних значень іншомовного слова.

Під час перекладу безеквівалентних термінів можливе поєднання кількох прийомів перекладу одночасно: використовувати калькування та транслітерації або транскрипції; транскрипції й описового перекладу тощо.

Перекладаючи багатокомпонентні терміни, необхідно встановити ключове слово та внутрішні смислові зв'язки [10, с. 49]. Наприклад, якщо розглядати термін immovable property gains tax, то спочатку перекладаємо ключове слово tax - податок, потім gains - прибуток і поєднання immovable property - нерухоме майно. Унаслідок отримуємо податок на прибуток від нерухомого майна.

Як стверджував В. Коптілов, переклад складних термінів передбачає два етапи: аналітичний та синтетичний. Важливим під час перекладу словосполучень $є$ саме аналітичний етап - переклад окремих його компонентів. А для цього необхідно правильно визначити компоненти складного терміна, оскільки ними можуть бути не лише слова, а й словосполучення, що входять до складу складного терміна $[8$, с. 85$]$.

Важливо зазначити, що під час перекладу термінів, необхідно враховувати контекст. Тлумачний словник або довідкове джерело можуть допомогти в поясненні значень терміна. Наприклад, слово rate позначає ставка в словосполученні interest rate, але у словосполученні inflation rate вживається у значенні 
рівень. Також необхідно враховувати географічні та країнознавчі реалії, уміти правильно добирати лексичну відповідність терміна або скористатися калькою в тому випадку, коли еквівалент в мові перекладу відсутній, перевіряти використання певного англійського терміна в оригіналі, перш ніж «упроваджувати» його в текст перекладу [14, с. 155-156].

Проблема неточного перекладу термінів має низку причин. По-перше, вибір невідповідного для кожного конкретного випадку значення будь-якого слова (зазвичай іменника). Ця помилка $\epsilon$ найбільш поширеною. Наприклад: government control часто перекладається словосполученням державний контроль, хоч правильним варіантом $є$ державне врегулювання. Іноді неправильний переклад дається не одному слову в конструкції, а всьому словосполученню, як-от: a public services revolution перекладається як револючія в побутових послугах замість реорганізація у сфері побутових послуг, work pressure - як робочий тиск замість вимоги до персоналу.

По-друге, терміни, особливо вузькоспеціалізовані, часто зрозумілі тільки фахівцям конкретної галузі наукового знання.

По-третє, іноді причиною помилки є неякісний підрядковий переклад, що є наслідком вищезгаданого та / або неуважність i відсутність ретельного лексико-семантичного аналізу терміна, а також його контекстуального значення.

Переклад термінів становить ядро науково-технічного перекладу, тому важливо знати особливості перекладу цього пласта лексики для досягнення максимальної еквівалентності. Під час перекладу термінів необхідно використовувати певні прийоми. Найбільш часто використовуються калькування, транслітерація, описовий переклад, інверсія тощо. Можливі варіанти використання кількох прийомів перекладу одночасно. У процесі перекладу термінів необхідно опиратися на контекст та враховувати особливості спеціалізації. 


\section{Література}

1. Акопова Э. Л. Безэквивалентные термины и способы их перевода / Э. Л. Акопова. - М., 2000. - 326 с.

2. Білозерська Л. П. Термінологія та переклад : [навчальний посібник] / Л. П. Білозерська, Н. В. Возненко, С. В. Радецька. - Вінниця : Нова книга, 2010. $232 \mathrm{c}$.

3. Борисова Л. І. Основні проблеми науково-технічного перекладу / Л. І. Борисова. - М. : МГУ, 2003. -208 с.

4. Борщовецька В. Д. Навчання студентів-економістів англійської фахової лексики: автореф. дис. ... канд. пед. наук / В. Д. Борщовецька. - К., 2004. - 20 с.

5. Динес Л. А. Вариантность терминологических единиц в частноотраслевой терминосистеме / Л. А. Динес // Лингвистические проблемы формирования и развития отраслевых терминосистем. - Саратов : Изд-во СГАП, 19976. - С. 19.

6. Карабан В. І. Переклад англійської наукової і технічної літератури. Граматичні труднощі та жанрово-стилістичні проблеми / В. І. Карабан. - Вінниця : Нова книга, 2002. $-407 \mathrm{c}$.

7. Кікец I. До питання про деякі труднощі при перекладі термінів і шляхи їх подолання / I. Кікец, Н. Кікец // Вісник державного університету «Львівська політехніка». - Львів : Львівська політехніка, 2000. - № 402. -420 с.

8. Коптілов В. В. Теорія і практика перекладу / В. В. Коптілов. -К., 2003. -185 с.

9. Лейчик В. М. Терминоведение. Предмет, методы, структура : [учебное пособие] / В. М. Лейчик. - М. : «Либроком», 2009. - 256 с.

10. Письменный перевод специальных текстов : [учебное пособие] / Е. А. Мисуно, И. В. Баценко, А. В. Вдовичев, С. А. Игнатова. - М. : ФЛИНТА : Наука, 2013. - 256 c.

11. Пронина Р. Ф. Перевод английской научно-технической литературы / Р. Ф. Пронина. - М. : Высшая школа, 1986. -175 с.

12. Сапальова Н. М. Використання в українському перекладі науковотехнічних термінів іншомовного походження / Н. М. Сапальова // Культура народів Причорномор'я. - 2001. - № 13. - С. 129-133.

13. Скороходько Е. Ф. Сучасна англійська термінологія / Е. Ф. Скороходько. - К. : Український інститут лінгвістики і менеджменту, 2002. - 76 с.

14. Слепович В. С. Перевод (английский - русский) : [учебное пособие] / В. С. Слепович. - Минск : ТетраСистемс, 2009. - 336 с.

Стаття надійшла до редакиії 15.02.2018 p. 